\title{
Formulating THE Korean SUPREME COURT'S STATURE AND ROLES: WITH A FOCUS ON THE RELATIONSHIP BETWEEN LEGISLATION AND PreCEDENTS $^{\dagger}$
}

\author{
by Justice Jae Hyung Kim (김재형)* \\ Translation by I.Y. Joseph Cho (조인영)**
}

\begin{abstract}
This essay/judicial speech is a modified English translation of Korean Supreme Court justice Jae Hyung Kim's presentation at the Conference of Chief Justices of Asia and the Pacific, which convened on September 19, 2017 in Tokyo, Japan. The relationship between legislation and case law is a highly important subject in the Korean Supreme Court's jurisprudence. Such relationship is relevant to statutory interpretation. The outcome of statutory interpretation is usually contingent upon how the judges understand and construct statute, a creature of the legislative body. Judges may differ in their approaches to
\end{abstract}

\footnotetext{
$\dagger$ This essay/judicial speech is a modified and updated English translation of Justice Kim's presentation at the Conference of Chief Justices of Asia and the Pacific, which convened on September 19, 2017 in Tokyo, Japan. The views and opinions expressed in this piece are those of the author and do not necessarily reflect the official position or policy of the Korean Supreme Court.
}

* Justice of the Supreme Court of Korea and former Professor of Law, Seoul National University School of Law. Prior to his appointment as a Korean Supreme Court justice in September 2016, Justice Kim was a professor at Seoul National University, School of Law since 1995. In that capacity, he participated in several legislative proceedings in South Korea involving the drafting of bills and legislative amendments. Some of the bills and legislative amendments Justice Kim drew up include amendments to the Korean Civil Code, revisions to the Debtor Rehabilitation and Bankruptcy Act, a bill on the Act on Security of Movable Property and Receivables, and revisions to the Framework Act on Electronic Commerce. In addition, Justice Kim has published articles on the construction of statutes (see in particular infra note 1) as well as various case commentaries on a number of Korean Supreme Court decisions. This essay was prepared based on Justice Kim's published articles and case commentaries as well as personal legislative experiences, to explain the Korean Supreme Court's stature and roles. The author wishes to thank all the Chief Justices and Supreme Court justices of participating jurisdictions at the above Conference for their helpful comments and feedback.

** A government contract lawyer (qualified in New York and in the United Kingdom) and SJD Candidate, Seoul National University School of Law. The translator wishes to thank his late father, JW Cho, for the exemplary life he led and for many fond memories he left behind. 
assessing the supremacy of statutory language or legislative will or whether to construe a statute contrary to its words in light of the overall purpose of that statue. In other words, the outcome of a judicial case may depend on whether the judge is willing to defer to the legislature, to plug certain perceived loopholes in a statute, or even to attempt purposive interpretation seemingly contradicting the statutory language. In this piece, I will review the roles and responsibilities of the Korean judiciary with a focus on the relationship between the legislature and courts. Towards this end, I will first discuss the Korean Supreme Court's jurisprudence on statutory interpretation. Such introduction will be followed by a discussion on some of the key Court decisions on the relationship between the two branches of government.

\section{INTRODUCTION}

It gives me tremendous honor and joy to present a speech at this honorable conference. Not unlike other free democratic states, the Republic of Korea is organized into three branches of the government. While the administrative branch is headed by an elected president, the National Assembly represents the legislative branch and the courts embody the judicial branch. This separation of powers prevents a concentration of public authority through a system of check and balance, while assuring the freedom and constitutional rights of the general public. Against this constitutional backdrop, it is important to assess how the legislative and administrative branch affect the judiciary in each court case and vice versa.

The precedents of courts have an important bearing on the process of legislation. As court precedents build up, they crystallize into jurisprudence, which then may find inroads into legislation. Conversely, new pieces of legislation may be introduced to rectify what is perceptibly wrong with the judge-made law.

Meanwhile, the relationship between legislation and case law is a highly important subject in the Korean Supreme Court's jurisprudence. Such relationship, first and foremost, is relevant to statutory interpretation. The outcome of statutory interpretation is usually contingent upon how the judges understand and construct statute, a creature of the legislative body. Judges may differ in their approaches to assessing the supremacy of statutory language or legislative will, or whether to construe a statute contrary to its words in light of the overall purpose of that statute. In other words, the 
outcome of a judicial case may depend on whether the judge is willing to defer to the legislature or to plug certain perceived loopholes in a statute or even to attempt purposive interpretation seemingly contradicting statutory language. Furthermore, judicial (in)activism remains an important subject of debate in the realm of judicial philosophy.

In this piece, I will attempt to review the roles and responsibilities of the Korean judiciary with a focus on the relationship between the legislature and courts. Towards this end, I will first discuss the Korean Supreme Court's jurisprudence on statutory interpretation. Such introduction will be followed by a discussion on some of the key Court decisions on the relationship between the two branches of government. I then look forward to hearing from today's participating luminaries.

\section{RELATIONSHIP BETWEEN THE LEGISLATURE AND JUDICIARY THROUGH THE PRISM OF STATUTORY INTERPRETATION}

The courts' primary role is to interpret and apply the law. In relation to this function, different conclusions may be arrived at depending on how the relationship between the legislature and the judiciary is assessed. Such assessment entails a probe into germane Korean jurisprudence. Of particular interest here is how Korean courts have weighed statutory language against the element of legislative intent or purpose in the context of statutory interpretation. ${ }^{1}$

Statutory words provide a fertile starting point for statutory interpretation. ${ }^{2}$ As a matter of principle, the court's role is to interpret a statute according to its text. In carrying out such textual interpretation, it is important to ascertain a possible meaning of the underlying text (möglicher Wortsinn) as well as what meaning the text conveys in the overall context of the statute. In the vast majority of relatively noncontroversial cases, the precedents of Korea are centered on textual or literary interpretation. ${ }^{3}$

\footnotetext{
${ }^{1}$ This Part is a summary of Kim Jae Hyung (김재형), Hwang-geumdeulnyeok-ui Aleumdaum: Beobhaeseog-ui Han Danmyeon (법학평론) [Splendor of Autumn Fields of Gold: an Aspect of Legal Interpretation], 1 BEOBHAK PYOUNGRON [SNU L. REV.] 223-229 (2010).

2 As the expression "( $\mathrm{t})$ he text... remains the alpha and omega of interpretation" demonstrates, the weight and importance of text are often emphasized in all types of interpretation including statutory interpretation. See Mary Ann Glendon, Comment, in A MATTER OF INTERPRETATION 106, 106 (Amy Gutmann eds., 1998).

${ }^{3}$ See, e.g., Supreme Court [S. Ct.], 93Da52808, Aug. 12, 1994 (S. Kor.).
} 
Interestingly, there are instances where, especially in the context of Supreme Court en banc judgments, dissenting justices criticized the majority as derogating from the usual rite of textual interpretation. For instance, the dissenting opinion in $95 \mathrm{Da} 3666$ noted that where the plain meaning of statutory language is unambiguous, attempting to otherwise widen or narrow such meaning is unwarranted unless there is a compelling need for purposive or teleological judicial interpretation of the same language. ${ }^{4}$ The majority's judgement in this case was considered by the dissenting opinion to be ultra vires and tantamount to re-legislating the statue at issue.

Also, the dissenting opinion in $2004 S u 42$ criticized the majority for having in effect arbitrarily altered what the minority viewed as the reasonably plain meaning of Article 120 of the Family Register Act. ${ }^{5}$ This opinion will be dealt with in more detail below. ${ }^{6}$ Moreover, in 94Moe32, a case involving the Korean Criminal Code, the dissenting judges pointed out that what underpins judicial interpretation of the criminal law is textual interpretation; accordingly, interpreting the Criminal Code in a way that exceeds the possible plain meaning of the Code amounts to an act of newly creating or re-legislating the penal enactment. ${ }^{7}$ These minority opinions point toward the flimsiness of boundaries between statutory interpretation and legislation.

Yet in a case where textual interpretation is found wanting, the adjudicating court may go on to consider the intent of the legislature and the purpose of the statute being scrutinized. ${ }^{8}$ In fact, on many occasions, the Court took on statutory interpretation by considering not only the legal text, but also the legislative intent and purpose of the enactment involved. ${ }^{9}$ For instance, the minority

${ }^{4}$ Supreme Court [S. Ct.], 95Da36466, Apr. 23, 1998 (S. Kor.).

5 Supreme Court [S. Ct.], 2004Su42, June 22, 2006 (S. Kor.).

6 See infra Part III.B.

7 Supreme Court [S. Ct.], 94Moe32, Dec. 20, 1994 (S. Kor.). For an interesting debate on interpretation of the criminal law in the aftermath of this decision, see SHIN DONG WOON (신동운) ET AL., BEOBLYULHAESEOG-UI HANGYE (법률해석의 한계) [The Limits of Statutory Interpretation] (2000).

8 The legislative intent here refers to that which is revealed during the process of legislation. When it comes to statutory interpretation, the legislator's subjective intent is not as important as in the context of interpreting contracts. See generally KARL LARENZ, METHODENLEHRE DER RECHTSWISSENSCHAFT [Methodology of Jurisprudence] $328\left(6^{\text {th }}\right.$ ed. 1991).

9 See e.g., Supreme Court [S. Ct.], 96Da54195, Apr. 22, 1997 (S. Kor.). 
opinion in 2006Doe4549 noted that interpretation of a criminal statute involves a process of clarifying the normative meaning of the statute for its application to a specific set of facts. ${ }^{10}$ The process of interpretation starts from ascertaining the linguistic meaning and content of the statutory provision being probed (textual interpretation) while at the same time, interpreting with logical consistencies in light of other related enactments (logical interpretation). Yet where following the text or underlying logic of a statute is insufficient to catch on the normative meaning of statutory language, the court should go on to consider, inter alia, legislative history, legislative intent and purpose, and function of the criminal provision in question (teleological interpretation). Albeit a minority opinion, it gracefully illustrates the method of statutory interpretation consistently adopted by the Court.

In cases where the text of a statute and its legislative intent or purpose collide, the question then becomes whether the court should prioritize the text itself or the intent or purpose meant by the legislature. A corollary to this issue is when, if ever, the court may interpret a statute contrary to its text. This has been the subject of ongoing scholarly and judicial debates for decades.

To start off, textualism requires a judge to duly adhere to the statutory text, and there is virtually no exception to this school of statutory construction. For instance, the late justice Scalia, a renowned textualist, asserted that a statute must be interpreted according to its text as there is no realistic means of fathoming the legislative intent behind it. ${ }^{11}$ Textualism is apparently at odds with intentionalism or purposivism. Under these theories, a statute is constructed in light of its legislative intent or statutory purpose, as the case may be. ${ }^{12}$ Under either theory, statutory interpretation that exceeds or contradicts the statutory text may be contemplated. Ronald Dworkin asserted that hard cases or "those cases in which the result is not clearly dictated by statute or precedent" $" 13$ should be tried according to the principle of law. ${ }^{14}$ He further espoused constructive

\footnotetext{
10 Supreme Court [S. Ct.], 2006Doe4549, Nov. 16, 2006 (S. Kor.).

11 ANTONIn SCAlia, A MATTER OF INTERPRETATION 23-25 (Amy Gutmann eds., 1998).

12 For a discussion on intentionalism and purposivism in the American context, see William N. ESKRidge JR. ET AL., LegisLATION AND StATUTORY INTERPRETATION (2006). See also KeNT GREENAWALt, LEGISLATION STATUTORY INTERPRETATION: 20 QUESTIONS (1999).

13 Ronald Dworkin, Hard Cases, 88 HARVARD L. REV. 1057 (1975).

14 RonAld DwORKIN, TAKING Rights SERIOUSLY 84 (1977).
} 
interpretation as a mode of statutory interpretation. ${ }^{15}$ This model of interpretation permits the best possible interpretation of a statute by considering related principles of law at the time of construction, which in turn leaves "headroom" for a mode of statutory interpretation that seemingly contradicts the legal text.

In Korea, there is a theory of law that statutory interpretation should generally proceed in the order of statutory text, legislative intent and statutory purpose. ${ }^{16}$ Yet determining if the legislative intent should precede the statutory purpose or vice versa in a given court case is far from easy. Codified law is expressed in words. The legislature's intent is reflected through the text of a statute, and such intent may not include what is on the subjective mind of responsible legislators. Granted, there may be cases where, due to linguistic barriers, ascertaining the meaning of statutory text is not feasible without knowing the legislative intent behind it. Considering the intent of the legislative body in such a case may be a commendable step towards understanding the meaning of the text. However, instructing the general public to self-study the subjective intent or opinion of the lawmaker, which may not be readily discernable from a plain reading of the text itself, and to act based on such selfknowledge, is akin to a recipe for disaster. Moreover, the purpose of a statute plays an important role in statutory interpretation. More often than not, skilled statutory interpretation is unattainable without probing the purpose of statute. In fact, interpreting the meaning of a statute by examining its legal raison d'être is fairly commonplace. Even where a court case refers to some legislative intent, such reference is usually directed to the objective purpose of the statute before the court, rather than any state of mind on the part of the lawmaker. Accordingly, statutory interpretation starts with the text; as an exception to this practice, there may be cases where the legislative intent or purpose may be considered as deemed appropriate.

In the meanwhile, it may be necessary to distinguish praeter legem from contra legem. The technique of praeter legem or statutory interpretation beyond the text is put to use where there is a legal lacuna or defect in a legislation, to make up for such an inherent gap or flaw.

15 Ronald Dworkin, Law's Empire 55 (1986). See also Andrei Marmor, INTERPRETATION AND LEGAL THEORY 36 (1992).

16 See SHIM Hun Sub (심헌섭), BunSEOGGWA BIPAN-Ui BEOBCHULHAG (분석과 비판의 법철학) [Legal Philosophy of Analysis and Criticism] 217 (2001). 
It is exemplified by analogy or analogical interpretation. By contrast, contra legem refers to a method of statutory interpretation that contradicts the literal meaning of the statutory text. As one can conjecture, while praeter legem is exercised relatively frequently, contra legem is attempted and acknowledged only in limited circumstances.

The Korean Court has held that praeter legem may be envisaged where textual or logical interpretation of the civil law alone is insufficient to resolve a real-life dispute. ${ }^{17}$ In such a case, analogical statutory interpretation may be employed instead to resolve the dispute in conformity with the notion of social justice and to eventually arrive at an equitable outcome. There is also a decision recognizing the possibility of contra legem where textual interpretation of a statute would have led to a rather unconscionable result. ${ }^{18}$ In this regard, the Court noted in another case that where a piece of legislation fails to keep up with social changes, the court's role is not merely to ask the legislature to revise or update the law and then wait for ensuing legislative follow-ups, but to try out a reasonably innovative method of statutory application to avoid an absurd outcome that could have arisen from customary, textual construction of the black letter law. ${ }^{19}$ Needless to say, any attempt at contra legem should be considered a rare exception, rather than the prevailing norm.

Where textual interpretation of a statute is likely to generate an outcome that flies in the face of the Constitution, the court may consider and adopt constitutionally compliant statutory interpretation, even though it may belie the statutory text. ${ }^{20}$ The court may also attempt contra legem using the basic principles of law. Yet caution should be taken here regarding routine acts of interpretation beyond the legal text simply because rationality or morality dictates so under the circumstances. Otherwise, the law may well lose its reason for being. Whether the law should consider any fabric of morality or reason and, if so, what should be considered moral or reasonable under a particular enactment, is better left to the legislature. The

\footnotetext{
17 Supreme Court [S. Ct.], 93Da52808, Aug. 12, 1994 (S. Kor.).

18 Supreme Court [S. Ct.], 98Da9038, Dec. 10, 1999 (S. Kor.).

19 Supreme Court [S. Ct.], 95Da36466, Apr. 23, 1998 (S. Kor.).

${ }^{20}$ In Korea, aside from the Supreme Court, which is the highest level of court, there is a separate constitutional court. HunBEOB [CONSTITUTION] art. 101.2 (S. Kor.). The Korean Constitutional Court is empowered to review the constitutionality of various legislations. HunBeob [Constitution] art. 111.1 (S. Kor.). The Court is not empowered to determine the constitutionality of court judgements, which largely distinguishes the Korean constitutional court system from the German counterpart.
} 
lawmaker's will or resolve may well be denigrated if a court were to hand down a decision squarely refuting the statutory text before it based on the court's own moral compass. ${ }^{21}$ Any attempt at justifying contra legem on the basis of morality or rationality, therefore, should be taken with a grain of salt.

\section{RELATIONS BETWEEN THE LEGISLATURE AND JUDICIARY AS REFLECTED IN THE KEY COURT JUDGEMENTS}

\section{A. Objective of Statutory Interpretation: A Balance between Legal Certainty and Case-specific Correctness}

The Supreme Court decision of 2006Da81035 is about the meaning of tenant under the Rental Housing Act of Korea ("RHA"). ${ }^{22}$ In this case, the Court addressed what forms the primary objective of statutory interpretation and related standards of interpretation. The plaintiff in this case, the Korea National Housing Corporation, leased an apartment to defendant $\mathrm{A}$ under the RHA. The rental contract was signed off by defendant $A$ under her own name. In fact, however, defendant B, defendant A's father, had asked his daughter to enter into the rental contract on his behalf. The security deposit came from defendant B, and the actual tenant of the leased apartment was also defendant B, not his daughter.

Under the RHA, after five years of a mandatory lease period, a tenant is entitled to purchase the rental property on a priority basis, provided the tenant is not the owner of another house or apartment from the onset of tenancy until the time of purchase. At the end of the lease, however, since defendant 1 already owned another house, she was not entitled to such priority purchase. And neither was defendant 2 entitled as he was not party to the original lease contract, and therefore not an eligible tenant. Following the expiry of the rental contract, the plaintiff sued both defendants for eviction and repossession of property.

In relation to who is a tenant under the RHA, the appellate court and the Supreme Court reached polar opposite conclusions. This difference in outcome may be attributed to dissonant judicial views on the nature of relationship between the judiciary and the

21 This does not mean that the meaning of statutory text ought to be interpreted according to the legislator's intent.

${ }^{22}$ Supreme Court [S. Ct.], 2006Da81035, Apr. 23, 2009 (S. Kor.). 
legislature. The appellate court rejected the plaintiff's request for an eviction order in the middle of a freezing winter, which then received media coverage as a "heartwarming decision of a beautiful judicial mind". ${ }^{23}$ The appellate court noted that, considering the policy objectives of the RHA, limiting the scope of tenant under the RCA to a tenant whose name and signature is on the lease would be a typical example of textual, formalistic statutory interpretation gone overboard. Considering the extenuating circumstances of defendant 2 here, the court considered him to be a tenant under the RHA for all intents and purposes. As such, defendant 2 was entitled to a priority purchase right under the RHA, and the remedies sought by the plaintiff were accordingly denied.

The Supreme Court, on the other hand, vacated the appellate court decision and remanded it. In so doing, the highest court noted that since the law embodies universal norms binding affected members of the public without discrimination, a court's legal interpretation should be a search for the objective meaning of the text involved and for legal certainty to ensure consistencies in interpretation. At the same time, statutory interpretation should proceed in a way that aims to provide the most apt solution to a set of facts before the adjudicating court. Accordingly, the Court held, the primary objective of statutory interpretation should be a pursuit of individual correctness within the overriding boundaries of legal certainty.

In this process, textual interpretation that identifies and construes to the extent possible the ordinary meaning of the statutory text should be a guiding norm. In addition, the legislative intent and purpose of the statute, its legislative chronology, and relationship to other pertinent enactments may be considered as part of a systematic and logical approach to statutory interpretation. Especially where the text of a statute consists of relatively unambiguous notions and terminologies, the court should not hesitate to employ textual interpretation for resolution of the case at hand.

In this case, the Court clarified that the aim of statutory interpretation is to achieve case-specific correctness without

${ }^{23}$ For a detailed analysis of the appellate judgement, see Kim Jae Hyung, supra note 1, at 200. This publication was originally prepared as a research paper on the appellate case at the request of a Supreme Court research judge and submitted to the Court in 2008. The 2006 Da81035 Court subsequently followed the same line of reasoning as laid out in the paper, which got published in 2010 . 
undermining legal certainty. Towards this end, textual interpretation should be considered a primary tool with possible consideration of other pertinent elements including the intent of the lawmaker. In this case, the RHA was devoid of a specific interpretive provision on the meaning of tenant thereunder. Accordingly, the Court took the liberty of construing the ordinary meaning of tenant according to how it is understood under the Civil Code ${ }^{24}$ as guided by general social norms. Under Article 618 of the Civil Code, a tenant denotes someone who has entered into a lease contract with the landlord. Under this type of contract, the tenant is given a bundle of rights including the right to quiet enjoyment of the rental property in consideration of the tenant's payment of rents. A de facto user or beneficiary of the property or the actual payor of the initial deposit or rents, fails to qualify as a tenant. This is what possibly prompted the Court to vacate the appellate decision.

\section{B. Judicial Response to Social Changes: Filling-in of Legislative Vacuums through Case Law}

Korea lacks express statutory provisions on how to implement the sex reassignment of a transgender person administratively. Under Korea's family registry system, a person's gender is recorded at the time of birth. When the same person undergoes a sex reassignment process later on, there is no administrative procedure to follow to modify the gender section on the family registry. Despite this status quo, in a recent en banc judgment, the Court granted sex reassignment of a transgender so that entries on the family registry may be revised to match the reassigned gender.

In the Korean Court decision of 2004Su42, the majority determined that sex reassignment of a transgender is feasible through statutory interpretation, while the dissenting judges opposed that determination. ${ }^{25}$ The concurring opinions supported the majority by espousing the notion of constitutional statutory interpretation. This seminal case exemplifies divergent views among the Court justices on the relationship between the legislature and the courts.

${ }^{24}$ Minbeob [Civil Code], Act No. 471, Feb. 22, 1958, amended by Act No. 14965, Oct. 31, 2017 (S. Kor.).

${ }^{25}$ Supreme Court [S. Ct.], 2004Su42, June 22, 2006 (S. Kor.). 
The applicant in this case was born a female in 1951 and registered so on her family registry. While growing up, however, the applicant exhibited masculine temperament and physical traits. In 1992, the applicant underwent successful sex change surgeries to obtain male sex organs and received ongoing hormone treatments thereafter. As a result, the applicant acquired masculine body traits as well as the firm gender identity of a man. The court of first instance and the appellate court both rejected the applicant's request to change the gender information on the family register citing a lack of statutory grounds to grant such a request. The Korean Court, however, vacated and remanded the decision below.

The Court noted that, judging by social norms, the applicant could be clearly evaluated a male. This is because the applicant was an unmarried person with no child who had acquired male sex organs and physical features as a result of previous surgeries. Also, considering the applicant's strong gender identity as that of a man, which had built up over the course of adolescence and adulthood, there was little likelihood of the applicant reverting back to the original gender. Moreover, the applicant was recognized as a male both in personal and social spheres.

But when it came to whether the sex reassignment of a transgender is administratively possible, the justices were divided. The majority acknowledged such possibility in the affirmative. They noted that Article 120 of the Family Register Act (currently Article 104 of the Act on the Registration, etc. of Family Relationships) ("FRA") provides for procedures to follow when correcting or modifying entries on the family register. This provision, they held, is applicable when changing the gender of a genuine transgender on the Register to conform to the reassigned gender.

In the majority's view, a transgender is someone whose gender at birth is different from the legally evaluated gender at the time of applying for a correction to the family register. Since, as members of the public, transgender persons have the right to pursue happiness and enjoy life as decent human beings, such request should be granted unless it is contrary to maintenance of the public order or welfare.

The majority held that the purpose of Article 120 of the FRA is to enable an applicant to correct the family registry when certain registry entries are inappropriate or do not match the applicant's current vital status. In light of this legislative aim, when it is verified 
that the applicant is a genuine transgender, it would be rational to permit the application to go through so that the family registry can duly reflect the applicant's newly acquired gender.

Two justices of the Court dissented. In their opinion, the purpose of FRA Article 120 is to remedy what was erroneously recorded on the family register at the time of birth report due to a clerical mistake or an error. Accordingly, if the family register truthfully matches an applicant's vital status and related entries at the time of birth report, subsequent changes including any gender reassignment may not provide grounds for invoking FRA Article 120 to correct the family register. The statutory text of FRA Article 120 is so unambiguous that any different construction is simply unwarranted. The majority opinion was therefore criticized for going beyond the outer limits of legitimate analogical interpretation. According to the dissenting judges, the Court's proper role was to acknowledge the absence of legal grounds to change the gender section of the family register in such a case as the present one and to urge the legislature to create a new enactment or to amend the FRA Article 120 regime in due time, to duly address the current controversy.

The concurring opinion supported the majority along the line of constitutional statutory interpretation. Namely, transsexual persons are exposed to a peculiar situation whereby their biological gender at birth does not match the gender they get to confirm while growing up and into adulthood. Given this peculiarity, correcting a transsexual's gender should be within the ambit of Article 120 of the FRA. Of course, enacting a new legislation to provide for such correction process would be most ideal. But in the absence of an existing legislative framework, the court should grant administrative correction of a qualified transsexual on a case-specific basis by recourse to constitutional statutory interpretation. In this regard, leaving transsexuals forlorn without a viable remedy would be unconstitutional.

This decision is a landmark. 2004Su42 put forward the following three pre-conditions to correct a transsexual's gender. ${ }^{26}$ First, there must be a medical diagnosis of transsexualism the symptoms of which remain unalleviated and continue. ${ }^{27}$ This should

\footnotetext{
${ }^{26} I d$.

27 Id.
} 
be accompanied by the affected individual's mental and social adjustive migration toward the opposite sex. Second, there must be gender reassignment surgery to enable the patient to acquire the sexual characteristics of the opposite $\operatorname{sex}^{28}$. Third, judging by general social norms, the transsexual must be seen as equipped with traits of the opposite gender, which then leads to normatively permissible correction of gender information. ${ }^{29}$

Not unlike Korea, Germany did not permit the gender correction of transsexuals until the German Federal Constitutional Court's decision in $1978 .{ }^{30}$ Unlike Korea, though, Germany enacted a statute called the Transsexuals Act in $1980 .{ }^{31}$ This legislation regulates the pre-conditions and effects of gender change in detail. For instance, the German legislation requires that an applicant for gender change be unmarried. ${ }^{32}$ If the applicant is married, then (s)he should get a divorce before the gender change is approved. ${ }^{33}$ Whether the applicant has any child in or out of wedlock is not relevant to the review process. ${ }^{34}$ This is because the legal effects of gender reassignment are not retroactive in nature. ${ }^{35}$ As a result, it does not affect or alter legal relations surrounding the transsexual's child). ${ }^{36}$ Once the court approves gender change, the

$28 I d$.

${ }^{29} I d$.

${ }^{30}$ BVerfGE, 1 BvR 16/72, Oct. 11, 1978. FCC held here that, seen from recognized fundamental rights pertaining to human dignity and freedom of expression, if the petitioner exhibited the symptoms of medically irreversible transsexualism and has consequently undergone sex change surgeries, the gender on his birth certificate should be accordingly modified. If such surgeries were medically proper, then the modification would not be contrary to public policy. It was noted that, in the absence of specific statutory grounds, FCC still owes a constitutional obligation to correct gender information on the petitioner's birth certificate.

31 The official German title of this enactment is Gesetz über die Änderung der Vornamen und die Feststellung der Geschlechtszugehörigkeit in besonderen Fällen.

32 See Gesetz über die Änderung der Vornamen und die Feststellung der Geschlechtszugehörigkeit in besonderen Fällen [Transsexuellengesetz].

[German Transsexuals Act] (promulgated on Sept. 10, 1980, effective on Jan. 1, 1981), art. 8.1.2, Bundesgesetzblatt Teil 1 at 56, 1656.

33 Rainer Frank, Europe, Teughi Dok-il-eseo Seongbyeol-ui Byeongyeong (유럽, 특히 독일에서 성별의 변경) [Gender Change in Europe, Particularly in the Context of Germany], 1 SEOUl DAEHAKGYo BEOBHAK (서울대학교 法學) [SEOul L.J.] 283, 291 (Kim Jae Hyung trans., 2006). This piece was presented at a comparative law conference organized by the Korean Supreme Court in September 2005, before the handing down of 2004 Su42.

34 Frank, supra note 33, at 291.

${ }^{35} \mathrm{Id}$.

36 See Gesetz über die Änderung der Vornamen und die Feststellung der Geschlechtszugehörigkeit in besonderen Fällen [Transsexuellengesetz]. 
rights and obligations of the applicant transsexual are determined in accordance with the reassigned gender. ${ }^{37}$

Korea has yet to have a similar enactment. It is therefore unclear under what conditions an application for gender change can be approved in the context of family register. It is speculated that since Korea currently prohibits same-sex marriage, the applicant should get a divorce before his or her application is granted. Whether the applicant has a minor child may be a factor in the review process; such fact, however, need not be an absolute bar to the application. In Korea, all these issues are being formulated and addressed through court precedents, as opposed to enactment.

\section{Judicial Influences on the Legislature: a Court Holding Prompting Enactment of a Statute}

The Korean Supreme Court decision of 2009Da17417 was a highly controversial case involving the suspension of life support for an old woman named Madame Kim. ${ }^{38}$ The plaintiff Kim fell into a persistent vegetative state while treated at a hospital run by the defendant (Yonsei University). Medical tests on the plaintiff revealed that her brain was in a serious state of shrinkage. The plaintiff's attending doctor gave the opinion that while she was incapable of voluntary control of breathing, the plaintiff was yet to be braindead with less than five chance of regaining consciousness. But other specialists who had examined her medical records noted that the plaintiff was in an ongoing state of coma and as good as braindead with little chances of recovery.

The plaintiff, a devout Christian, was dependent on a ventilator for survival. While she was healthy and conscious, the plaintiff expressed her desire not to burden anyone for protracted medical care or assistance to her. She also expressed her wish not to depend on life support in a fatal medical emergency.

The plaintiff requested that the defendant stop further lifeprolonging treatment. The Court accepted that request. The

\footnotetext{
[German Transsexuals Act] (promulgated on Sept. 10, 1980, effective on Jan. 1, 1981), art. 11, Bundesgesetzblatt Teil 1 at 56, 1656.

37 See Gesetz über die Änderung der Vornamen und die Feststellung der Geschlechtszugehörigkeit in besonderen Fällen [Transsexuellengesetz].

[German Transsexuals Act] (promulgated on Sept. 10, 1980, effective on Jan. 1, 1981), art. 10, Bundesgesetzblatt Teil 1 at 56, 1656.

38 Supreme Court [S. Ct.], 2009Da17417, May. 21, 2009 (S. Kor.).
} 
2009Da17417 court noted that while recognizing a patient's right to self-determination in the context of life-prolonging treatment, one's right to life is precious and is quintessential to all fundamental rights. ${ }^{39}$ As such, whether to stop any medical treatment that bears on a patient's life requires an extremely cautious decision. The Court was divided on what constitutes the threshold for allowing lifeprolonging treatment to be suspended. ${ }^{40}$ According to the majority, the threshold is met where: (i) the patient has reached the irreparable phase of death; and (ii) the patient has previously communicated his or her intent that life-prolonging treatment be suspended. ${ }^{41}$

In relation to the first element, the irreparable phase of death is reached when there is no likelihood for the patient to regain consciousness and to recover the loss of vital signs; it must be clear that the patient may die within a short period without life support. ${ }^{42}$ In relation to the second element, if the patient had expressly communicated his or her intent that life-prolonging treatment be suspended when reaching the irreparable phase of death, such communicated intent would be honored and followed through. ${ }^{43}$ The problem arises when there is no such patient communication. In that instance, according to the majority, the patient's consent may be presumed when it becomes objectively apparent that suspending lifeprolonging treatment would be in the patient's best interests. ${ }^{44}$ In this regard, what is critical is if, in light of the patient's usual values and belief system while conscious, the patient would have consented to the suspension of life-prolonging treatment, had (s)he been given a chance to provide informed consent. Making such a presumption on behalf of the patient would not be contrary to common sense nor to social norms. ${ }^{45}$

If there is any evidence pointing to a terminally-ill patient's intent, be it express or implied, to refuse or stop life-prolonging

${ }^{39} I d$. Article 10 of the Korean Constitution guarantees all citizens' human worth and dignity. HunBeOB [CONSTITUTION] art. 10 (S. Kor.). One's right to life is arguably derived from this constitutional provision. See Supreme Court [S. Ct.], 2000Da37524, 37530, Jan. 22, 2002 (S. Kor.).

40 Supreme Court [S. Ct.], 2009Da17417, May. 21, 2009 (S. Kor.).

${ }^{41}$ Id.

${ }^{4} I d$.

${ }^{43} I d$.

${ }^{44} I d$.

45 Id. 
treatment, the court may order the treatment to be suspended. ${ }^{46}$ In the absence of leading evidence, the minority noted, suspension of medical treatment may still be justified from the standpoint of legal order in general. ${ }^{47}$ For instance, the medical institution responsible for the patient's treatment may be obliged to suspend further lifeprolonging treatment as part of its implied obligations under the underlying treatment contract.

In relation to whether suspension of life-prolonging treatment is permitted, there was no applicable legislation at the time of this case. Despite this status quo, the Court answered in the affirmative by putting certain legal theories to use. As noted above, the $2009 D a 17417$ court drew the conclusion that life-prolonging treatment may be suspended in accordance with the patient's right to self-determination. In the process, the Court also applied civil law theories relating to interpretation of juristic acts or of expressions in formulating the pre-requisites for suspension of treatment. Following 2009Da17417, the legislature has recently enacted a statute on lifeprolonging treatment. ${ }^{48}$ This can be considered an instance where the judiciary nudged the legislature into action.

\section{Complimentary Relations between the Legislative and Judiciary}

What was the main issue in 2008Da45828, another en banc Court judgement, was a matter of interpretation involving who should be party to a bank deposit contract under Korea's real-name financial system. ${ }^{49}$ On February 13, 2006, the plaintiff's husband ("A") opened a new fixed term account ("Account") with a commercial bank ("B") on the plaintiff"s behalf. A deposited KRW 42 million to the Account. On the application for the Account, both the plaintiff's name and resident number were entered, along with a copy of the plaintiff's photo identification. The bankbook of the Account was issued in the plaintiff's name, and B's transactional records showed the plaintiff as the owner of the Account.

\footnotetext{
${ }^{46} I d$.

47 Id.

${ }^{48}$ Hoseupiseu Wanhwauilyomit Imjong-gwajeong-e Itneun Hwanjaui Yeonmyeonguilyo Gyeoljeong-e Gwanhan Beoblyul [Act on Decisions on Hospice and Palliative Care and Decisions on Life-sustaining Treatment for Patients at the End of Life], Act No. 15542, Mar. 27, 2018 (S. Kor.).

49 Supreme Court [S. Ct.], 2008Da45828, Mar. 19, 2009 (S. Kor.).
} 
The appellate court found an implied agreement between A and $\mathrm{B}$ that $\mathrm{A}$, as opposed to the plaintiff, was party to the underlying deposit contract. The Court, on the other hand, vacated this finding. ${ }^{50}$ In so holding, the Court made it clear that, under the real name financial system, where a bank deposit contract is duly entered into after real name verification of the account holder, only the account holder is entitled to withdraw the fund deposited. This is the case unless there is an unusual circumstance indicating the meeting of minds both the bank and the actual depositor of fund intended the depositor, rather than the account holder, to be party to the banking contract. This ratio was on point and in the right direction. ${ }^{51}$

Who is party to a bank deposit contract is a matter of contract interpretation. Especially in the context of rather voluminous and repetitive financial transactions such as banking contracts, it becomes necessary to determine who is party to such a contract in a relatively routine and effortless manner. In this regard, the determinative criterion is who was objectively presented to the bank as the account holder after a real name verification process. This process is in conformity with Article 3.1 of the Act on Real Name Financial Transactions and Confidentiality ("Real Name Act"). The provision requires financial transactions to proceed on a real-name basis. What can be inferred from this statutory requirement is that only the account holder with a verified real name may be party to the underlying transaction and the parties' implied consent to such contract formation. This mutual assent then leads to only the account holder constituting a legitimate party to the banking contract. ${ }^{52}$

Korea first introduced a real name financial system in 1993. In 1997, the Real Name Act was enacted. Under the enactment,

$502008 D a 45828$ consists of the majority opinion, a separate concurring opinion, and two supporting opinions.

${ }^{51}$ For academic views in support of 2008Da45828, see Oh Young Joon (오영준), Geumyungsilmyeongjeha-eseo Yegeumgyeyag-ui Dangsaja Hwagjeong bangbeob [How to determine the parties to the deposit agreement under the real-name financial system], 8 SABEOB (사법) [JURIS], 265 (2009). See also Sohn Chul Woo (손철우), Geum-yungsilmyeongjewa Yegeumju Hwagjeong (금융실명제와 예금주 확정) [Real Name Financial System and Determination of the Account Holder], MinsAPANRAEYEONGU (XXXII) (민사판례연구 (XXXII)) [STU. Of CIV. CASES (XXXII)] 155 (2010).

${ }^{52}$ Kim Jae Hyung (김재형), GEUM-YUNG-GEOLAEUI DANGSAJA-E GWANHAN PANDANGIJUN (금융거래의 당사자에 관한 판단기준) [CRITERIA FOR DETERMINING THE PARTIES TO FINANCIAL TRANSACTIONS], MinBEOBRON(III)(민법론 (III)) [CIV. L. ThEORIES (III)] 70 (2007). This piece was presented at the $55^{\text {th }}$ comparative law seminar hosted by the Korean Supreme Court in May 2006. 
financial transactions ought to proceed on a real name basis. Adoption of a real name financial system and subsequent enactment of the Real Name Act has affected related court cases. Before 2008Da45828, the Court was willing to recognize the scope of account holder to include any actual depositor of the fund deposited, even if the full name of the account holder differed from that of the depositor. ${ }^{53}$ But, since 2008Da45828, the Court has drastically narrowed this, so that in Korea today, only the account holder is considered party to the banking contract, in the absence of very special circumstances. The Court's jurisprudence has greatly contributed to increased transparency of financial transactions in general.

Legislation can affect the contours of jurisprudence; yet the practical extent of such influence is largely up to the courts to fathom and apply. The enactment of the Real Name Act did not provide concrete guidelines for determining who is party to a banking contract. It was up to the judiciary and legal academics to deliberate on and produce germane guidelines. In this case, the Court succeed in resolving what remained an outstanding issue under the Act based on its scrutiny of how the Act defines the parties to a bank deposit contract. 2008Da45828 thus illustrates how the legislature and judiciary complement each other in practice.

\section{E. The Impacts of Case Law on Social Changes}

2015 Da200111 is a recent landmark Korean Court case. ${ }^{54}$ It has generated prompt and fiery reactions from the Korean legal community and society at large. In this case, the plaintiff paid out $\mathrm{KRW}^{55} 100,000,000$ as a success fee to his lawyer according to an attorney contingency fee agreement in a related criminal case. The plaintiff subsequently sued the lawyer to return the fee. The case below found that 40 percent of the success fee (that is, KRW 40 million) was out of proportion contrary to the principle of good faith and trust or of equity and hence null. As such, the defendant was obligated to return KRW 40 million to the plaintiff. While dismissing

53 See, e.g., Supreme Court [S. Ct.], 99Da67031, Mar. 10, 2000 (S. Kor.). The author called for changes to the existing line of case law. See Kim, supra note 52, at 73-77, 88.

54 Supreme Court [S. Ct.], 2015Da200111, July 23, 2015 (S. Kor.).

$55 \mathrm{KRW}$ refers to South Korean won (1 USD = approximately 1,130 KRW at the time of writing). 
the defendant's appeal, the Court unanimously found that: (i) contingency fee agreements in criminal cases are considered contrary to the standard of good morals and public order as encapsulated in Article 103 of the Civil Code; (ii) this finding applies to contingency fees for criminal cases going forward; any such fee arrangements predating the current judgement may not be deemed null per se; and (iii) the contingency fee plan in this case predates the Court's opinion; as such, it cannot be readily adjudged that the plan is null ab initio as contrary to Article 103 . But, the decision of the case below that 40 percent of the success fee is excessive and hence void was upheld.

a. Are contingency fees in criminal cases against public policy and therefore void?

2015 Da200111 is a highly meaningful precedent in light of its declaration that contingency fees for criminal cases are null as contravening social order and that this ratio is only effective going forward and not retroactively. An attorney's contingency fee regime in a criminal case refers to a financial arrangement whereby the client agrees to pay special fees to the attorney depending on the outcome of the case or on an agreed rate of success. The issue here is whether to acknowledge the fee regime's legal effects under freedom of contract or deny them as contrary to public policy or the overarching principle of good faith and trust.

Academics have exhibited a whole spectrum of opinions ranging from the view that the contingency fee arrangement is valid as an extension of freedom of contract to the assertion that contingency fees in criminal cases are generally void. The Court previously upheld in principle the validity of contingency fee schemes in criminal cases, subject to the caveat that the adjudicating court may only uphold a portion of the success fee by applying the principle of good faith and equity. ${ }^{56} 2015$ Da200111 reversed the prior jurisprudence by holding the illegality of criminal contingency fees on public policy grounds. In so doing, the Court considered whether such fee schemes are against the general morals of Korean society or pose a risk to the public's trust in the criminal justice system as a whole.

\footnotetext{
56 See, e.g., Supreme Court [S. Ct.], 2009Da21249, July 9, 2009 (S. Kor.).
} 
Whether the Court's conclusion in 2015Da200111 is justifiable remains controversial. Lawyers and members of the general public may well react differently. Nevertheless, this decision is certainly not beyond the normative ambits of the Korean civil law system. The civil law of Korea is largely based on the principle of freedom of contract. Members of the public are thus free to engage in civil and commercial activities of their own formulation. Under Article 103 of the Civil Code, however, a juristic act that is contrary to social order may be rendered null. Also, the principle of good faith and trust, as encapsulated in Article 2 of the Civil Code, is at work to ensure that the outcome of a given case conforms to the norms of equity. Prior jurisprudence of the Court attempted to address the open issue of criminal contingency fee agreements by envisaging the possibility of reducing success fees based on the principle of good faith and trust. The 2015Da200111 court, by contrast, nullified the contingency fee scheme as contrary to Article 103. It is hence clear that both judicial approaches to the same issue are anchored on doctrinal tenets of the civil law.

b. Did the Court err in acknowledging only the prospective effect of changes in precedents?

2015 Da200111 denied the retroactive effect of changes in case law. Namely, the Court considered it difficult to nullify existing contingency fee schemes under Article 103 of the Civil Code. The controversy in 2015Da200111 could be addressed by reference to the existing jurisprudence. Yet the Court took the further step of overturning its own prior jurisprudence to signal the firm policydriven resolve that changes to the criminal contingency fee scheme and related practices were in order.

\section{c. Post script}

As can be imagined, criminal defense attorneys have vehemently opposed 2015Da200111. They have argued that any flaw with the contingency fee system should be resolved through legislation, rather than any judicial pronouncement. This argument is not without merit in that there is no statute or statutory provision expressly dealing with the subject of contingency fees for criminal cases. Despite this legislative vacuum, the 2015Da200111 court 
chose to make proactive use of Article 103 of the Civil Code, a statutory provision of general application, to declare that criminal contingency fee agreements are void as against public order. ${ }^{57}$ This, in my opinion, exemplifies judicial activism. ${ }^{58}$ In fact, 2015 Da200111 is one of the handful of Court cases from the last decade evincing judicial activism. The relative scarcity of these cases makes them highly influential in shaping the judicial landscape of Korea. Needless to say, judicial activism is neither an unswerving principle nor a path to tread all the time. At the end of the day, what policy stance a court is to assume in a given case would be as important as the doctrinal issues underpinning that case.

\section{CONCLUSION}

One of the Court's primary roles is to provide uniform points of reference for interpreting various statutes. Such role is reified differently in different cases. While pursuing legal certainty, the Court also attempts to achieve case-specific correctness in sync with the ideals of justice. In this process, the legislature and judiciary may be in complementary or strained relations with one another, depending on the context.

The legislature and judiciary may not claim absolute supremacy over the other. Rather, they are like two wheels of a cart in pursuit of the common objective called justice. This symbiotic relationship is expected to go a long way in cultivating a healthy state and society at large.

Social changes will invariably entail new sets of problems. Legislation may not be a panacea here. In order for the Court to assume a visionary role in this milieu, it must be equipped with precise understandings of the Constitution and other laws of the land to provide timely, reasonable and often creative legal solutions. Relying on the individual judges' sense of equity or justice will be only a part of the equation. The Court's precedents will lack persuasiveness and coherence without adequate theological

\footnotetext{
57 Id.

58 In support of the majority, the supporting opinion in 2015Da20011 put forward legal maxims relating to trust in the judicial system, the public's legal consciousness, comparative law materials, and positive future effects of the Court's enunciation in this case. These suggested elements are highly unconventional in the Korean judicial system and forward-looking, which, in my opinion, are reminiscent of judicial activism.
} 
underpinnings. In its ongoing quest for such legal acumen, the Korean Supreme Court has greatly benefitted not only from soul searching inside, but also from comparative studies of the noteworthy experiences of other jurisdictions. I have no doubt that this conference will provide a useful forum for hearing what each attendant representing the highest court in each participating jurisdiction, has to offer during the course of this forum and in the future. Thank you. 